\title{
POTENSI DAN STATUS KONSERVASI IKAN DI BENDUNGAN LAKITAN KABUPATEN MUSI RAWAS, PROVINSI SUMATERA SELATAN
}

\author{
Dian Samitra ${ }^{1}$, Zico Fakhrur Rozi ${ }^{1}$ \\ ${ }^{1}$ Prodi Pendidikan Biologi, STKIP-PGRI Lubuklinggau, Lubuklinggau \\ Coressponding author: dian.samitra@gmail.com
}

\begin{abstract}
This study aims to determine the potential and conservation status of fish in Lakitan Dam Musi Rawas Regency. This research was conducted in February until April 2018. The location of the research was determined by using purposive sampling technique. The samples were collected by using scatter nets and the subsequent identification was done in the Biology Laboratory of STKIP PGRI Lubuklinggau. Conservation status data is determined by IUCN Redlist while fish potential data is obtained from interview with the surrounding community. A total of 17 fish species were found during the study, divided into categories not evaluated 8 species (47\%), 8 species (47\%) least concern and 1 species (6\%) data deficient. While the potential of fish as fish consumption as many as 12 species (62\%), 3 species (23\%) ornamental fish as well as fish consumption and ornamental fish as many as 2 species (15\%).
\end{abstract}

Keywords: Lakitan Dam, Potential Fish, Conservation Status

\section{PENDAHULUAN}

Bendungan adalah tembok yang dibangun untuk menghambat aliran sungai yang digunakan sebagai penyedia sumber air irigasi dan minum, untuk pembangkit listrik, mengendalikan banjir serta menjadi tempat rekreasi (Imhof et al., 2006; Dharmayasa et al., 2014). Bendungan Lakitan merupakan bendungan ke dua di Kabupaten Musi Rawas, Provinsi Sumatera Selatan. Bendungan Lakitan dibangun pada tahun 2006 dan mulai difungsikan pada tahun 2015 , bendungan ini difungsikan untuk mengairi 11.000 hektar sawah (Antara News, 2013; Berita Satu, 2015; Trianto et al., 2016).

Hasil observasi yang dilakuakan oleh peneliti pada tanggal 3 Januari 2018, diperoleh informasi bahwa Bendungan Lakitan dijadikan sumber air irigasi untuk area pertanian masyarakat sekitar, selain itu perairan bendungan juga dijadikan tempat masyarakat untuk beraktvitas serta pemenuhan kebutuhan sehari-hari diantaranya seperti mandi dan mencari sumber pangan berupa ikan. Masyarakat sekitar bendungan tidak mempunyai peraturan khusus dan larangan tertentu terkait tata cara penangkapan ikan di wilayah bendungan, tidak seperti lubuk larangan di Sumatera Barat, kegiatan menangkap ikan dilakukan pada waktu-waktu tertentu. Adanya alih fungsi daerah aliran sungai, aktivitas manusia dan proses sidementasi berpotensi di bendungan akan menimbulkan permasalahan tersendiri bagi ekosistem perariran dan dapat merugikan kelangsungan hidup organisme di sekitar Bendungan Lakitan khususnya ikan yang melakukan migrasi ke bagian hulu untuk berkembang biak (Samitra dan Rozi, 2018; Samuel dan Adjie, 2008; Simanjuntak, 2012). Kerusakan habitat ikan di suatu perairan menyebabkan hanya sebagian area perairan yang masih mendukung kehidupan ikan. Oleh karena itu, ikan yang semula memiliki 
penyebaran yang luas menjadi terbatas pada beberapa bagian areal saja (Sadili et al, 2015).

Penelitian dan eksplorasi ikan di perairan tawar khususnya di sungai telah banyak dilakukan di pulau Sumatera. Tercatat 123 jenis teridentifikasi di perairan hutan Harapan Jambi (Sukmono et al., 2013), 79 jenis teridentifikasi di Sungai Musi, Sumtera Selatan (Samuel dan Adjie, 2008), 5 jenis ikan air tawar didapatkan di Muara Sungai Musi (Prianto dan Suryanti, 2010), dan 13 jenis teridentifikasi di Sungai Kelingi, Kota Lubuklinggau (Samitra dan Rozi, 2018). Hasil penelitian terdahulu belum membahas potensi dan status konservasi ikan sehingga pemanfaatan dan status konservasi ikan tidak tercatat dengan baik.

Eksplorasi jenis-jenis ikan di Bendungan Lakitan sangat penting dilakukan untuk melengkapi informasi jenis ikan dan keanekaragaman hayati di Indonesia khususnya Pulau Sumatera. Informasi tentang ikan yang lengkap akan menjadi landasan yang kuat untuk kegiatan restorasi dan konservasi/pelestarian ikan (Sukmono et al., 2013). Penelitian ini bertujuan untuk mengkaji jenis-jenis, potensi dan status konservasi ikan di Bendungan Lakitan.

\section{METODE PENELITIAN}

\section{Metode}

Jenis penelitian ini adalah penelitian deskriptif eksploratif dengan menggunakan teknik survei yang dilakukan dengan cara menentukan titik lokasi pengamatan di
Bendungan Lakitan. Pengumpulan data ikan dilakukan dengan cara menjelajah titik lokasi yang telah ditentukan, pengambilan ikan dengan teknik survei perjumpaan menggunakan jaring pencar dan tangguk.

Penelitian dilaksanakan pada bulan Februari hingga April 2018. Penelitian dilakukan di Bendungan Lakitan Kabupaten Musi Rawas Provinsi Sumatera Selatan. Peneliti mengambil sampel di seluruh area Bendungan Lakitan pada pukul 08.00-10.00 dan 16.00-18.00. Pengambilan sampel dilakukan dengan pengulangan sebanyak 5 kali, sampel ikan yang didapat kemudian bawa ke Laboratorium Pendidikan Biologi STKIP PGRI Lubuklinggau untuk diidentifikasi dan dilacak status konservasinya berdasarkan panduan Froese dan Pauly (2018), proses pelacakan dilakukan dengan memasukan binomial nomenclature pada menu nama spesies sehingga akan muncul database status konservasi.

Data potensi ikan diperoleh dengan cara menggali informasi melalui wawancara mengenai pemanfataan ikan oleh masyarakat sekitar Bendungan Lakitan (Sadili et al., 2015). Untuk menggali informasi tersebut, ikan yang tertangkap diperlihatkan pada masyarakat sekitar, kemudian peneliti menghimpun data potensi ikan dengan teknik wawancara untuk menggali informasi berlandaskan kebiasaan masyarakat memanfaatkan ikan yang berada di sekitar Bendungan Lakitan. 
Samitra, Dian \& Rozi, Zico Fakhrur: Potensi dan Status Konservasi Ikan di Bendungan Lakitan Kabupaten Musi Rawas, Provinsi Sumatera Selatan

\section{Alat dan Bahan}

Alat yang digunakan pada penelitian ini adalah jaring pencar, tangguk, kantong plastik, botol koleksi, mistar, alat tulis, mistar, kamera digital, kertas label dan life jacket. Bahan yang dibutuhkan pada penelitian adalah aqudest, larutan formalin 10\%, dan alkohol $70 \%$.

\section{Teknik pengumpulan dan analisis data}

Prosedur penelitian untuk pengumpulan sampel ikan adalah sebagai berikut: 1) pengambilan sampel dilakukan di stasiun yang telah ditetapkan dengan menggunakan jaring pencar dan tangguk; 2) sampel ikan yang diperoleh difoto dengan menggunakan kamera digita (kegiatan foto tersebut diperlukan untuk mengatasi hilangnya pola warna ikan saat direndam dengan formalin (Hadiaty, 2011); 3) sampel dimasukan ke dalam toples berisi larutan formalin $10 \%$ untuk difiksasi kemudian akan diawetkan dengan alkohol 70\% (Samitra dan Rozi, 2018); 4) Sampel penelitian dibawa ke laboratorium Biologi STKIP-PGRI Lubuklinggau untuk diamati; dan 5) Kegiatan identifikasi dilakukan di laboratorium berpedoman pada buku Kottelat et al. (1993).

Data sampel ikan yang teridentifikasi dianalisis secara deskriptif kuantitaif yang meliputi data status konservasi dan data potensi ikan. Data sebaran ikan berpedoman pada Kottelat, et al. (1993). Data status konservasi berpedoman pada Froese dan Pauly (2018). Data potensi ikan diperoleh dari wawancara dengan masyarakat sekitar
Bendungan Lakitan dan berpedoman pada buku Said dan Hidayat (2015) dan Sukmono et al. (2013).

\section{HASIL DAN PEMBAHASAN}

\section{Hasil}

Penelitian ini dilakukan di Bendungan Lakitan Kabupaten Musi Rawas Provinsi Sumatera Selatan. Bendungan Lakitan memiliki luas 9.450 ha dan difungsikan sebagai sumber air irigasi untuk area pertanian warga. Sumber air Bendungan Lakitan adalah Sungai Lakitan. Kondisi Bendungan Lakitan sangat terpelihara dengan baik dan tidak ada sampah di bendungan tersebut. Ikan yang berhasil ditangkap dan teridentifikasi di Bendungan Lakitan selama penelitian sebanyak 17 spesies yang terdiri dari 6 famili (Tabel 1). Spesies-spesies tersebut dapat dideskripsikan sebagai berikut.

Famili Cyrpinidae

\section{Barbonymus gonionotus}

Ikan ini memiliki 4 duri keras, 8 duri lunak pada sirip dorsal. Memiliki 3 duri keras, 6 duri lunak pada sirip anal. Panjang tubuh 9 cm. Sirip ekor bewarna kuning. Dari hasil wawancara dengan masyarakat ikan ini dijadikan ikan konsumsi dan selama penelitian tertangkap sebanyak 15 ekor ikan.

\section{Barbodes lateristriga}

Masyarakat memanfaatkan ikan ini sebagai ikan hias dan konsumsi. Selama penelitian tertangkap 8 ekor ikan. Barbodes lateristriga memiliki ciri-ciri duri sirip dorsal sebanyak 8, duri sirip anal sebanyak 5 . 
Panjang tubuh 9,5. Sirip ekor berwarna kuning. Terdapat garis kuning vertikal dibagian tengah tubuh dan garis longitudinal.

\section{Hampala microlepidota}

Masyarakat memanfaatkan ikan ini sebagai ikan konsumsi. Selama penelitian tertangkap sebanyak 9 ekor ikan. Ikan ini memiliki ciri-ciri terdapat 11 duri lunak pada sirip dorsal. Memiliki 8 duri lunak pada sirip anal. Panjang tubuh $45 \mathrm{~cm}$. Terdapat garis hitam antara sirip dorsal dan sirip perut. Tepi sirip ekor berwarna hitam.

\section{Lobocheilos ixocheilos}

Ikan ini memiliki ciri-ciri terdapat 11 duri lunak pada sirip dorsal. Memiliki 8 duri lunak pada sirip anal. Panjang tubuh $12 \mathrm{~cm}$. Tidak terdapat garis hitam pada tubuh. Masyarakat memanfaatkan ikan ini sebagai ikan konsumsi dan selama penelitian tertangkap sebanyak 6 ekor ikan.

\section{Osteochilus waandersii}

Ikan ini memiliki 12 duri lunak pada sirip dorsal. Panjang tubuh $10,3 \mathrm{~cm}$. Terdapat garis hitam pada tubuh dari celah insang hingga dekat ekor. Warna sirip kemerahmerahan. Masyarakat memanfaatkan ikan ini sebagai ikan konsumsi dan selama penelitian tertangkap sebanyak 2 ekor ikan.

\section{Schismatorhynchos heterorhynchos}

Ikan ini memiliki ciri-ciri tidak terdapat garis hitam pada tubuh dari celah ingsang hingga dekat ekor, warna sirip hitam dan panjang tubuh $22,5 \mathrm{~cm}$. Bagian kepala/moncong seperti hidung yang terbelah.
Masyarakat memanfaatkan ikan ini sebagai ikan konsumsi dan selama penelitian tertangkap sebanyak 7 ekor ikan.

\section{Labiobarbus fasciatus}

Ikan ini memiliki ciri-ciri duri sirip dorsal sebanyak 27 , panjang tubuh $18,3 \mathrm{~cm}$. Terdapat garis hitam pada tubuh hingga dekat ekor. Warna sirip ekor dan punggung kemerah-merahan. Masyarakat memanfaatkan ikan ini sebagai ikan konsumsi dan selama penelitian tertangkap sebanyak 17 ekor ikan.

8. Cyclocheilichtys apogon

Masyarakat memanfaatkan ikan ini sebagai ikan hias dan konsumsi. Selama penelitian tertangkap sebanyak 15 ekor ikan. Ikan ini memiliki 4 duri keras dan 8 duri lunak pada sirip dorsal. Panjang tubuh $12,9 \mathrm{~cm}$. Terdapat titik hitam pada pangkal ekor dan warna sirip ekor kemerah-merahan.

\section{Osteochilus vittatus}

Ikan ini memiliki 17 duri lunak pada sirip dorsal, 8 duri lunak pada sirip anal, panjang tubuh $18 \mathrm{~cm}$. Tidak terdapat garis hitam pada tubuh dan terdapat bercak bulat pada pangkal ekor. Masyarakat memanfaatkan ikan ini sebagai ikan konsumsi. Selama penelitian tertangkap sebanyak 6 ekor ikan.

\section{Crossocheilus obscures}

Ikan ini memiliki 17 duri lunak pada sirip dorsal., 8 duri lunak pada sirip anal. Panjang tubuh $11,4 \mathrm{~cm}$. Tidak terdapat garis hitam pada tubuh. Sirip bewarna putih. Masyarakat memanfaatkan ikan ini sebagai 
Samitra, Dian \& Rozi, Zico Fakhrur: Potensi dan Status Konservasi Ikan di Bendungan Lakitan Kabupaten Musi Rawas, Provinsi Sumatera Selatan

ikan konsumsi. Selama penelitian tertangkap putih. Sirip ekor berwarna abu-abu dengan sebanyak 7 ekor ikan.

Famili Bagridae

\section{Mystus nigriceps}

Masyarakat memanfaatkan ikan ini sebagai ikan konsumsi. Selama penelitian tertangkap sebanyak 2 ekor ikan. Ikan ini memiliki 4 kumis di sekitar mulut. Panjang tubuh $12 \mathrm{~cm}$. Ditemukan dua titik hitam di badan. Tubuh tidak bersisik

\section{Hemibagrus velox}

Masyarakat memanfaatkan ikan ini sebagai ikan konsumsi. Selama penelitian tertangkap sebanyak 5 ekor ikan. Ikan ini memiliki 1 duri keras dan 7 duri lunak pada sirip dorsal. Memiliki 11 duri lunak pada sirip anal. Panjang tubuh $16 \mathrm{~cm}$. Tubuh bewarna hitam. Tubuh tidak bersisik.

\section{Bagroides melaptertus}

Masyarakat memanfaatkan ikan ini sebagai ikan konsumsi. Selama penelitian tertangkap sebanyak 6 ekor ikan. Ikan ini memiliki 1 duri keras dan 7 duri lunak pada sirip dorsal. Memiliki 11 duri lunak pada sirip anal. Panjang tubuh $12 \mathrm{~cm}$. Tubuh warna kuning dan bermotif hitam. Sirip ekor bewarna kuning. Sirip dorsal dan perut berwarna hitam dengan ujung berwarna kuning serta tubuh tidak bersisik.

\section{Famili Pangsidae}

\section{Pangasius micronemus}

Ikan ini memiliki mata yang cukup besa dan mempunyai 28 duri lunak pada sirip anal. Panjang tubuh 13,8 cm. Tubuh warna Masyarakat memanfaatkan ikan ini sebagai ikan konsumsi. Selama penelitian tertangkap sebanyak 10 ekor ikan.

\section{Famili Tetraodontidae}

\section{Pao leiurus}

Ikan ini memiliki ciri-ciri moncong sedikit panjang, panjang tubuh $11 \mathrm{~cm}$, wdarna tubuh hijau dengan lingkaran hitam yang berpola dan tidak bersisik. Masyarakat tidak memanfaatkan ikan ini sebagai ikan konsumsi tetapi memiliki potensi sebagai ikan hias. Selama penelitian tertangkap sebanyak 6 ekor ikan.

\section{Famili Belonidae}

\section{Xenentodon canciloides}

Masyarakat tidak memanfaatkan ikan ini sebagai ikan konsumsi dikarenakan baunya yang sangat amis, ikan ini dimanfaatkan sebagai ikan hias. Selama penelitian tertangkap sebanyak 8 ekor ikan. Ikan ini memiliki ciri-ciri panjang tubuh $25 \mathrm{~cm}$, warna tubuh abu-abu, tubuh tidak bersisik dan mulut seperti gergaji.

Famili Mastacembelidae

\section{Mastaecembelus maculates}

Masyarakat memanfaatkan ikan ini sebagai ikan hias, tetapi memiliki potensi sebagai ikan hias. Selama penelitian tertangkap sebanyak 3 ekor ikan. Ikan ini memiliki ciri-ciri panjang tubuh $18,5 \mathrm{~cm}$, warna tubuh hitam, tubuh tidak bersisik, tipe 
ekor membundar dan tidak memiliki duri keras pada sirip.

Ikan air tawar dapat dimanfaatkan sebagai ikan konsumsi dan ikan hias. Ikan air tawar yang dikonsumsi memiliki kriteria daging cukup tebal, rasa ikan yang enak dan termasuk ikan prolifik (Dani et al., 2005). Ikan hias memiliki kriteria bentuk tubuh yang unik dan warna tubuh menarik (Pulungan, 2009). Data pemanfaatan ikan di Bendungan Lakitan diperoleh dari wawancara kepada masyarakat sekitar bendungan dan studi pustka buku Said dan Hidayat (2015) dan Sukmono et al., (2013)

Ikan di Bendungan Lakitan berpotensi sebagai ikan konsumsi sebanyak 12 spesies (62\%), 3 spesies (23\%) berpotensi ikan hias serta sebagai ikan konsumsi dan ikan hias sebanyak 2 spesies (15\%) (Gambar 2). Ikan yang paling diminati oleh masyarakat adalah Hampala microlepidota, Mystus nigriceps, Hemibagrus velox, Barbonymus gonionotus, Cyclocheilichtys apogon, dan Osteochilus vittatus. Hal ini dikarenakan ikan-ikan tersebut memiliki rasa yang enak.

Merujuk kepada definisi umum International Union for Conservation of the Nature (IUCN), yang dimaksud dengan jenis ikan terancam punah adalah biota ikan yang rentan akan kepunahan dalam waktu dekat (EN - endangered). Tingkat kerterancaman suatu spesies ditentukan berdasarkan karakteristik dinamika populasi ikan tersebut yang merupakan fungsi dari kelahiran, pertumbuhan, dan kematian. Secara sederhana dapat diartikan bahwa pada kondisi ini kecepatan kematian akibat penangkapan dan faktor lainnya termasuk penyakit, predator, gangguan lingkungan, maupun penyebab alamiah lainnya, melebihi kecepatan rekrutmen (pertambahan populasi melalui kelahiran). Ketiga faktor dinamika populasi tersebut merupakan ukuran dari critical dispensation (dispensasi kritis), yakni secara matematis mengukur biomassa terhadap pertumbuhan populasi (Sadili et al., 2015).

Berdasarkan status konservasi menurut International Union for Conservation of the Nature (IUCN) Redlist (Froese dan Pauly, 2018) ikan di Bendungan Lakitan terbagi kedalam kategori belum dievaluasi (not evaluated) 7 spesies (41\%), 9 spesies (50\%) kategori beresiko rendah (least concern) dan 1 spesies (6\%) kategori kurang data (data deficient) (Gambar 3). Dari jumlah ikan yang tertangkap (pada tabel 1) memperlihatkan bahwa tidak semua ikan-ikan yang berstatus least concern banyak ditemukan ikan-ikan tersebut yaitu, Mastaecembelus maculates hanya ditemukan 3 ekor, Osteochilus waandersii ditemukan 2 ekor. Ikan yang berstatus data deficient ditemukan sebanyak 10 ekor. Ikan Lobocheilos ixocheilos, Mystus nigriceps, Bagroides melapterus, dan Hemibagrus velox yang berstatus not evaluated ditemukan dalam jumlah sedikit. 
Samitra, Dian \& Rozi, Zico Fakhrur: Potensi dan Status Konservasi Ikan di Bendungan Lakitan Kabupaten Musi Rawas, Provinsi Sumatera Selatan
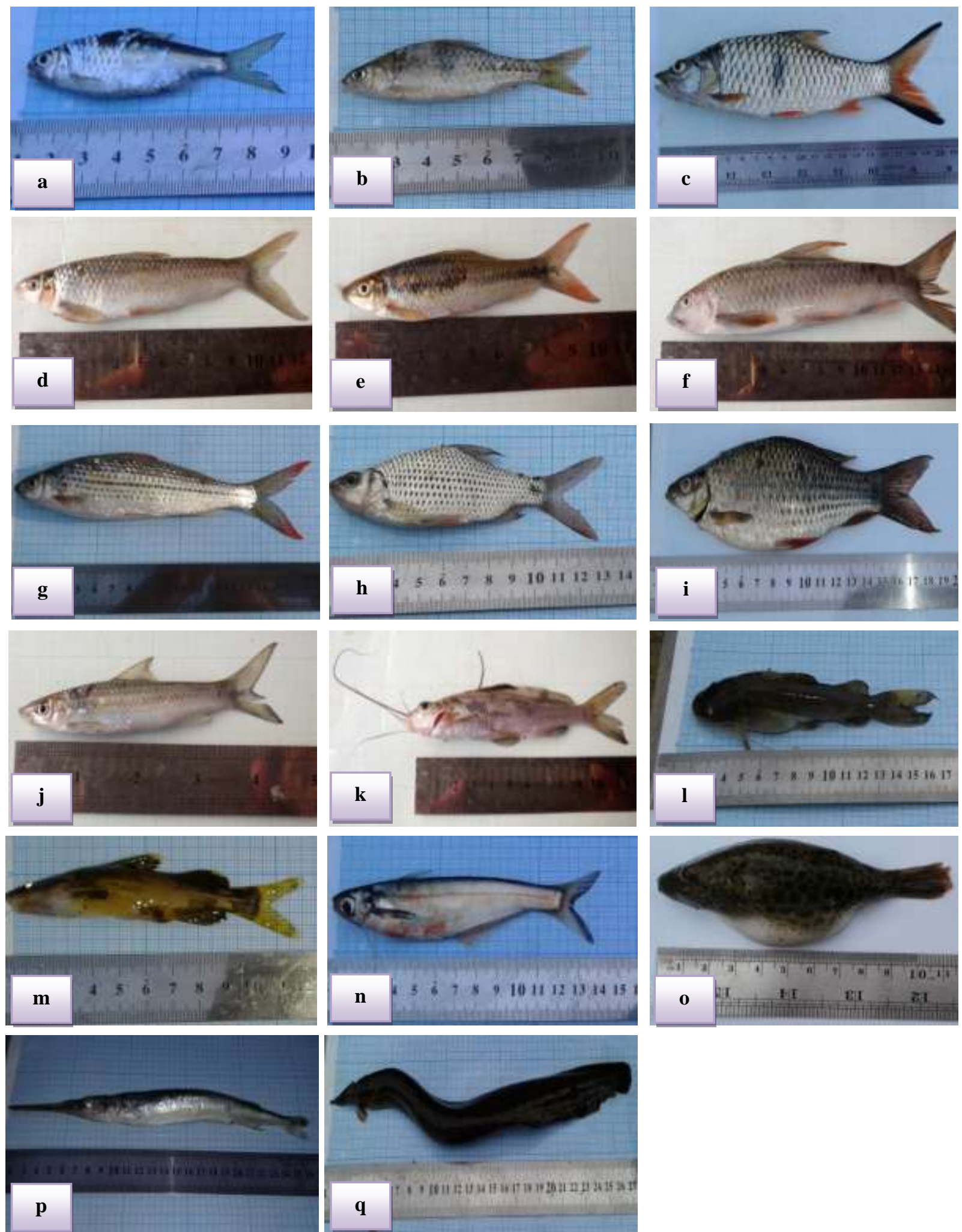

Gambar 1. Jenis ikan di Bendungan Lakitan: (a). Barbonymus gonionotus; (b). Barbodes lateristriga; (c). Hampala microlepidota; (d). Lobocheilos ixocheilos; (e). Osteochilus waandersii; (f). Schismatorhynchos heterorhynchos; (g). Labiobarbus fasciatus; (h). Cyclocheilichtys apogon; (i). Osteochilus vittatus; (j). Crossocheilus obscures; (k). Mystus nigriceps; (1). Hemibagrus velox; (m). Bagroides melaptertus; (n). Pangasius micronemus; (o). Pao leiurus; (p). Xenentodon canciloides; (q). Mastaecembelus maculates. 


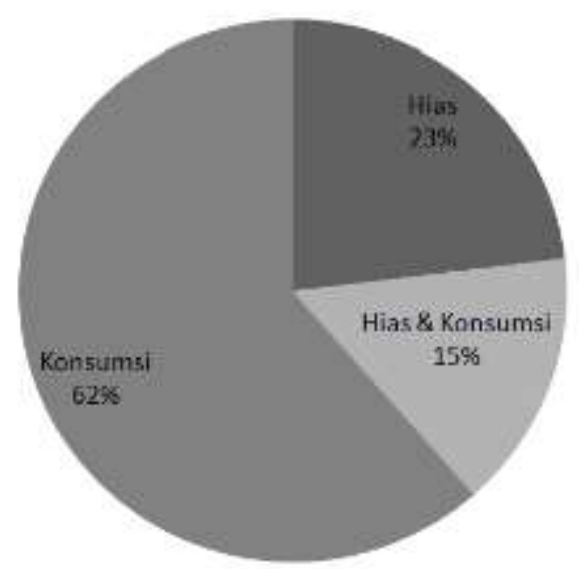

A

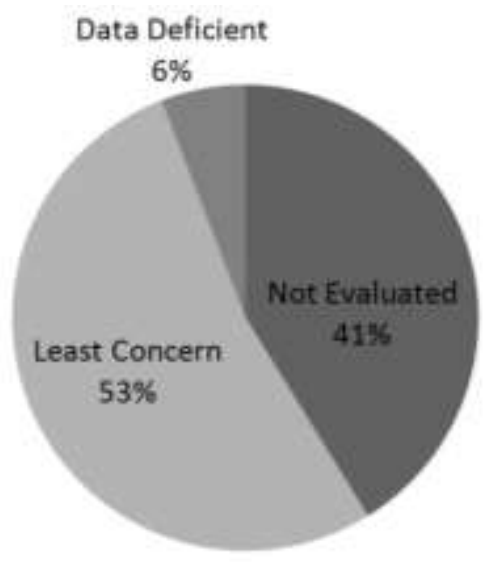

B

Gambar 2. A. Grafik Potensi Ikan di Bendungan Lakitan; B. Status Konservasi Ikan di Bendungan Lakitan

Tabel 1. Jumlah Individu, Potensi dan Status Konservasi Ikan di Bendungan Lakitan

\begin{tabular}{|c|c|c|c|}
\hline Famili/Spesies & Jumlah Individu & Potensi & Status Konservasi* \\
\hline \multicolumn{4}{|l|}{ Cyprinidae } \\
\hline Barbonymus gonionotus & 15 & Konsumsi & Least Concern \\
\hline Barbodes lateristriga & 8 & Hias dan Konsumsi & Least Concern \\
\hline Hampala microlepidota & 9 & Konsumsi & Least Concern \\
\hline Lobocheilos ixocheilos & 6 & Konsumsi & Not Evaluated \\
\hline Osteochilus waandersii & 2 & Konsumsi & Least Concern \\
\hline $\begin{array}{l}\text { Schismatorhynchos } \\
\text { heterorhynchos }\end{array}$ & 7 & Konsumsi & Not Evaluated \\
\hline Labiobarbus fasciatus & 17 & Konsumsi & Not Evaluated \\
\hline Cyclocheilichtys apogon & 15 & Hias dan Konsumsi & Least Concern \\
\hline Osteochilus vittatus & 6 & Konsumsi & Least Concern \\
\hline Crossocheilus obscures & 7 & Konsumsi & Not Evaluated \\
\hline \multicolumn{4}{|l|}{ Bagridae } \\
\hline Mystus nigriceps & 2 & Konsumsi & Not Evaluated \\
\hline Hemibagrus velox & 5 & Konsumsi & Not Evaluated \\
\hline Bagroides melapterus & 6 & Konsumsi & Not Evaluated \\
\hline \multicolumn{4}{|l|}{ Pangsidae } \\
\hline Pangasius micronemus & 10 & Konsumsi & Data Deficient \\
\hline \multicolumn{4}{|l|}{ Tetraodontidae } \\
\hline Pao leiurus & 6 & Hias & Least Concern \\
\hline \multicolumn{4}{|l|}{ Belonidae } \\
\hline Xenentodon canciloides & 8 & Hias & Least Concern \\
\hline \multicolumn{4}{|l|}{ Mastacembelidae } \\
\hline $\begin{array}{l}\text { Mastaecembelus } \\
\text { maculates }\end{array}$ & 3 & Hias & Least Concern \\
\hline
\end{tabular}




\section{Pembahasan}

Sebanyak 17 spesies ikan yang tergolong kedalam 6 famili berhasil ditangkap selama penelitian dan tidak ditemukan ikan endemik yang tertangkap di Bendungan Lakitan. Hasil penelitian tidak berbeda dengan penelitian lainnya, dimana jumlah ikan-ikan cyprinidae merupakan ikan yang paling banyak ditangkap dan ikan konsumsi merupakan ikan yang paling banyak ditemukan (Simanjuntak et al., 2006; Sukmono et al., 2013).

Ikan-ikan tersebut yaitu Mystus nigriceps dengan nama daerah baung dapat ditemukan di perairan Indonesia dan Thailand, jenis ini memiliki peranan sebagai ikan konsumsi, ikan ini ditemukan pada perairan yang mengalir atau tergenang dan menjadi predator. Hemibagrus velox nama daerah baung dapat ditemukan di perairan Sumatera, ikan ini menjadi ikan konsumsi oleh masyarakat dan ikan ini hidup sebagai predator. Bagroides melapterus mempunyai nama daerah baung pisang dapat ditemukan di perairan Sumatera, Kalimantan dan Thailand, ikan ini dijadikan ikan konsumsi oleh masyarakat dan menjadi predator. Barbonymus gonionotus mempunyai nama daerah kapiat dapat ditemukan Sumatera, Jawa, Sulawesi dan Malaysia, ikan ini memiliki peranan sebagai ikan konsumsi. Barbodes lasteriga dengan nama daerah kapiul dapat ditemukan di perairan Sumatera, Kalimantan dan Malaysia, ikan ini memiliki peranan sebagai ikan konsumsi dan dapat dijadikan ikan hias. Hampala microlepidota dengan nama daerah kebarau dapat ditemukan di Pulau Sumatera dan Kalimantan, ikan ini memiliki peranan sebagai ikan konsumsi.

Lobocheilos ixocheilos mempunyai nama daerah khili dapat ditemukan di perairan Sumatra dan Kalimantan, ikan ini memiliki peranan sebagai ikan konsumsi. Osteochilus waandersii mempunyai nama daerah seluang dapat ditemukan di Sumatera, Kalimantan dan Malaysia, ikan ini memiliki peranan sebagai ikan konsumsi.

Schismatorhynchos heterorhynchos mempunyai nama daerah cawang hidung dapat ditemukan di Sumatera dan Kalimantan, ikan ini memiliki peranan sebagai ikan konsumsi. Cyclocheilichtys apogon mempunyai nama daerah kepras dapat ditemukan di Sumatera, Kalimantan, dan Malaysia, ikan ini memiliki peranan sebagai ikan konsumsi. Osteochilus vittatus mempunyai nama daerah kepalau dapat ditemukan di Sumatera, Jawa, Kalimatan dan Malaysia, ikan ini memiliki peranan sebagai ikan konsumsi. Crossocheilus obscurus mempunyai nama daerah ikan tanah dapat ditemukan di Sumatera, ikan ini memiliki peranan sebagai ikan konsumsi. 
Mastaecembelus maculatus mempunyai nama daerah tilan dapat ditemukan di Sumatera, Jawa, Kalimantan, Malaysia, dan Thailand, ikan ini memiliki peranan sebagai ikan hias.

Pao leiurus mempunyai nama daerah buntal dapat ditemukan di Indonesia dan Srilanka ikan ini memiliki peranan sebagai ikan hias. Xenentodon canciloides mempunyai nama daerah nyulung dapat ditemukan di Indonesia, Malaysia dan Thailand, ikan ini memiliki peranan sebagai ikan hias. Pangasius micronemus mempunyai nama daerah jiho kocor dapat ditemukan di Sumatera, Jawa dan Thailand, ikan ini memiliki peranan sebagai ikan konsumsi.

Hasil identifikasi dan analisis daerah asal ikan, tidak ditemukan ikan introduksi di Bendungan Lakitan, hal ini menunjukan bahwa masyarakat belum melepaskan ikanikan asing ke Bendungan Lakitan. Jika terdapat ikan introduksi dikhawatirkan akan membahayakan kelestarian ikan asli (endemik) karena ikan introduksi dapat berkembang biak dengan sangat cepat serta menjadi kompetitor bagi ikan asli untuk mendapatkan makanan (Hadiaty, 2011).

Hasil pengambilan sampel diperoleh ikan yang paling banyak tertangkap adalah famili Cyprinidae sebanyak 10 spesies. Banyak Cyprinidae yang ditemukan pada Bendungan Lakitan, merupakan hal yang umum terjadi di perairan khususnya wilayah Sumatera. Cyprinidae merupakan ikan yang mendominasi perairan Sumatera, Jawa dan Bali, tercatat 1058 spesies yang sudah teridentifikasi (Rahardjo et al., 2011).

Hasil analisis data diperoleh 7 spesies (41\%) ikan berstatus belum dievaluasi (Not Evaluated), dan 1 spesies (6\%) ikan berstatus kurang data (Data Deficient). Hal tersebut menunjukan bahwa keanekaragaman ikan air tawar masih kurang mendapat perhatian (Sukmono, et al., 2013). Sebanyak 9 spesies (53\%) ikan berstatus resiko rendah (least concern), hal ini dapat diartikan 9 spesies ikan tersebut masih banyak ditemukan di alam, tetapi dari tabel 1, beberapa spesies yang ditemukan seperti Osteochilus waandersii, Mastaecembelus maculates dan Pao leiurus jumlah yang tertangkap sangat sedikit sehingga perlu ada kajian status konservasi. Status belum dievaluasi menyebabkan suatu jenis ikan yang sudah diambang punah, tidak dilakukan upaya pelestarian atau konservasi, hal ini dapat terlihat pada hasil tangkapan dimana ikan yang berstatus not evaluated yaitu ikan Lobocheilos ixocheilos, Mystus nigriceps, Bagroides melapterus, dan Hemibagrus velox ditemukan dibawah 7 ekor ikan. Sebanyak 52 jenis ikan endemik Sumatera belum dievaluasi sehingga perlu adanya penelitian agar ikan-ikan tersebut dikaji status konservasinya (Prianto, et al., 2016). Pada 
Samitra, Dian \& Rozi, Zico Fakhrur: Potensi dan Status Konservasi Ikan di Bendungan Lakitan Kabupaten Musi Rawas, Provinsi Sumatera Selatan

kegiatan penelitian tidak ditemukan ikan yang terancam punah dan endemik Sumatera seperti Rasbora sumatrana.

Ikan di Bendungan Lakitan didominasi oleh ikan konsumsi ditemukan sebanyak 12 spesies (62\%). Banyaknya ikan konsumsi yang ditemukan sama dengan hasil peneitian terdahulu dimana dari 123 spesies ikan yang tertangkap 58 spesies (47\%) dapat dikonsumsi, 35 spesies (29\%) sebagai ikan hias dan 30 spesies (24\%) berpotensi sebagai ikan konsumsi dan hias (Sukmono et al., 2013). Ikan konsumsi di Bendungan Lakitan dengan nilai penting yaitu Hampala microlepidota, Cyclocheilichtys apogon, dan Hemibagrus velox. Ikan-ikan konsumsi akan menjadi sumber pencaharian dan dapat meningkatkan perekonomian masyarakat sekitar Bendungan Lakitan apabila dikelola dengan baik. Hasil dari wawancara dengan nelayan dan masyarakat sekitar, ikan yang paling banyak dicari untuk dimasak adalah Hemibagrus velox, dan Hampala microlepidota. Masyarakat sekitar belum memanfaatkan ikan di Bendungan Lakitan sebagai ikan hias padahal di Bendungan Lakitan terdapat ikan hias yang sudah dikenal oleh para penggemar ikan hias. Ikan-ikan yang dapat dikembangkan menjadi ikan hias adalah Barbodes lasteriga, Pao leiurus, Mastaecembelus macalatus, Rasbora sumaterana. Hasil kajian pustaka ditemukan bahwa ikan
Hampala microlepidota dan Barbonymus gonionotus mempunyai nilai ekonomi yang sedang (Kottelat et al.,1993).

Selama kegiatan penangkapan/pengambilan sampel tidak banyak jumlah ikan yang didapatkan. Belum ada catatan terkait jumlah atau keanekaragaman spesies ikan di Bendungan Lakitan menyulitkan peneliti untuk membandingkan dengan hasil penelitian terdahulu. Jumlah tangkapan yang sedikit ini memperlihatkan bahwa sumber daya ikan telah mengalami penurunan drastis akibat aktivitas dan eksploitasi ikan yang berlebihan serta adanya alih fungsi daerah aliran sungai (DAS) menjadi bendungan (Prianto et al., 2015).

Kegiatan pelestarian atau konservasi perlu dilakukan untuk memulihkan keanekaragaman spesies yang ada di Bendungan Lakitan. Salah satu kegiatan yang dapat dilakukan adalah rehabillitasi habitat, regulasi kouta penangkapan dan penerapan pengaturan waktu penangkapan ikan (Prianto et al., 2015). Selain itu perlu dilakukan identifikasi penyebab menurunnya populasi ikan diarea yang akan dikonservasi sehingga bisa diatasi untuk menanggulangi permasalahan tersebut (Dudgeon et al. 2006). Peranan masyarakat lokal dalam kegiatan konservasi dapat menjadi penentu keberhasilan upaya tersebut. Selain bertujuan untuk mempertahankan biodiversitas, 
melestarikan eksistensi spesies, memelihara kesehatan lingkungan perairan, dan mempertahankan keberlanjutan perikanan, penebaran kembali jenis ikan lokal ke habitat aslinya memiliki makna dan tujuan sosio-kultural dan historis penting bagi masyarakat setempat. Oleh karenanya, peningkatan kebutuhan pangan ikan, pengembangan ekonomi lokal, dan upaya dalam menjunjung tinggi nilai-nilai lokal (kearifan lokal) harus ditempatkan sebagai bentuk penghargaan kepada masyarakat sekitarnya di mana wilayah perairannya akan dijadikan kegiatan restoking (Sadili et al., 2015).

\section{KESIMPULAN}

Berdasarkan pembahasan di atas, maka simpulan dalam artikel ini adalah sebagai berikut.

1. Ikan yang teridentifikasi di Bendungan Lakitan berjumlah 17 spesies.
2. Status konservasi ikan di Bendungan Lakitan, berdasarkan kategori dari International Union for Conservation of the Nature sebanyak 9 spesies (53\%) berstatus least concern, 7 spesies (41\%) berstatus not evaluated, dan 1 spesies (6\%) berstatus data deficient.

3. Ikan di Bendungan Lakitan didominasi oleh ikan konsumsi.

\section{UCAPAN TERIMA KASIH}

Ucapan terima kasih kepada diucapkan kepada Sekolah Tinggi Keguruan dan Ilmu Pendidikan Persatuan Guru Republik Indonesia (STKIP-PGRI) Lubuklinggau dan Kementerian Riset dan Teknologi karena penelitian ini dapat terselenggara melalui hibah skim Penelitian Dosen Pemula yang diperoleh oleh peneliti.

\section{DAFTAR PUSTAKA}

Antara News. 2013. Bendungan Sungai Lakitan mulai berfungsi tahun depan. Online

at https://www.antaranews.com/berita/40 1495/bendungan-sungai-lakitanmulai-berfungsi-tahun-depan [diakses 2 Agustus 2018].

Berita Satu. 2015. Pemkab Musirawas fungsikan irigasi baru Bendungan Lakitan. Online at http://www.beritasatu.com/makro/304 033-pemkab-musirawas-fungsikanirigasi-baru-bendungan-lakitan.html [diakses 2 Agustus 2018].
Dani NP, Agung Budiharjo, Shanti Listyawati. 2005. Komposisi pakan buatan untuk meningkatkan pertumbuhan dan kandungan protein ikan tawes (Puntius javanicus Blkr.) BioSMART, 7 (2): 83-90.

Dharmayasa I, Redana I, dan Suwarsa Putra T. 2014. Analisis keamanan lereng Bendungan Utama pada Bendungan Benel di Kabupaten Jembrana. Jurnal Spektran, 2(2): 6877.

doi:10.24843/SPEKTRAN.2014.v02.i 02.p09 
Samitra, Dian \& Rozi, Zico Fakhrur: Potensi dan Status Konservasi Ikan di Bendungan Lakitan Kabupaten Musi Rawas, Provinsi Sumatera Selatan

Dudgeon D, AH Arthington, MO Gessner, Zen-Ichiro Kawabata, DJ Knowler, C Le've^que, RJ Naiman, A-H PrieurRichard, D Soto, MLJ Stiassny, and CA Sullivan. 2006. Freshwater biodiversity: importance, threats, status and conservation challenges. Biological Reviews, 81(2). 163-182. doi: $10.1017 /$ S1464793105006950.

Froese R and Pauly D. 2018. Fish Base. World Wide Web electronic publication. Online at www.fishbase.org [diakses pada tanggal 28 Juli 2018].

Hadiaty RK. 2011. Diversitas dan kehilangan jenis ikan di danau-danau aliran Sungai Cisadane. Jurnal Iktiologi Indonesia, 11(2): 143-157.

Imhof A, AK Schneider, and S. Wong. 2006. Dams, rivers and right's: an action guide for communites affected by dams. USA: International Rivers Networks.

Kottelat M, JA Whitten, SN Kartikasati, dan S Wirjoatmojo. 1993. Ikan air tawar Indonesia bagian barat dan Sulawesi edisi dwi bahasa IndonesiaInggris. Periplus Edition, 293 p.

Prianto E dan Suryanti NK. 2010. Komposisi jenis dan potensi sumber daya ikan di muara sungai musi. Jurnal Penelitian dan Perikanan Indonesia, 16(1): 1-8.

Prianto E, R Puspasari, ES Kartamihardja, N Zulfia, P Rachmawati, dan D Oktaviani, 2015. Kajian kebijakan konservasi sumber daya ikan di Paparan Sunda. Prosiding Nasional Ikan Ke-8, 29-40.

Pulungan CP. 2009. Fauna ikan dari Sungai Tenayan, anak Sungai Siak, dan rawa Di sekitarnya, Riau. Berkala Perikanan Terubuk, 37 (2): 78-90.
Rahardjo MF, Syafei DS, Affandi R, dan Sulistiono. 2011. Iktiology. Bandung: CV Lubuk Agung.

Sadili, Didi, Haryono, Kamal M. Mukhlis, Sarmintohadi, dan Ramli Ihsan. 2015. Pedoman Umum Restoking Jenis Ikan Terancam Punah. Jakarta: Direktorat Konservasi Kawasan Dan Jenis Ikan Ditjen Kelautan, Pesisir dan PulauPulau Kecil Kementerian Kelautan dan Perikanan.

Said, Djamhuriyah Syaikh dan Hidayat. 2015. 101 Ikan Hias Air Tawar Nusantara. LIPI PRESS.

Samitra D dan Rozi ZF. 2018. Keanekaragaman ikan di Sungai Kelingi kota Lubuklinggau. Jurnal Biota, 4(1): 1-6.

Samuel S dan Adjie S. 2008. Zonasi, karakteristik fisika-kimia air dan jenis-jenis ikan yang tertangkap (Zonation, physico-chemical characteristic of water and fish species of Musi River ). Ilmu Perairan Dan Perikanan Indonesia, 15(1): 41-48.

Simanjuntak CPH. 2012. Keragaman dan distribusi spasio-temporal iktiofauna Sungai Asahan bagian hulu dan anak sungainya. Prosiding Seminar Nasional Ikan, VII: 43-60.

Sukmono T, Solihin DD, Rahardjo MF, dan Affandi R. 2013. Iktiofauna di perairan hutan tropis dataran rendah, Hutan Harapan Jambi. Jurnal Iktiologi Indonesia, 13(2): 161-174.

Trianto R, Ussy Andawayanti, dan Runi Asmaranto. 2016. Analisis laju sedimentasi terhadap ketersediaan air irigasi dan arahan konservasi pada Bendung Lakitan. Jurnal Pengairan, 7(1): 95-106. 